\title{
Serum Uric Acid Level and Inflammation in Obese Medical Students at Ain Shams University
}

\author{
HEBATALLAH S. ALY, M.D.*; REEM M. SALLAM, M.D.* and MARIAN M.S. ROUSHDY, M.D.** \\ The Department of Medical Biochemistry \& Molecular Biology* and Medical Biochemistry \& Molecular Biology \\ Department and Clinical Nutrition**, Faculty of Medicine, Ain Shams University
}

\begin{abstract}
Background: Overweight and obesity occur when excess fat accumulation increases risk to health, leading to expression of co-morbid diseases occur at different thresholds. That's why obesity is now recognized as a chronic or noncommunicable disease.

Aim of Study: To assess serum uric acid and diet contributing in its increased concentration level in relation to inflammation in a subsample of obese medical students as compared to normal-weight medical students in Faculty of Medicine Ain Shams University.

Subjects and Methods: The current study is a case control study of 63 students among 1220 Ain Shams medical students. Our study group was divided into two groups. Group 1 included 30 students with BMI between $18.5-24.9 \mathrm{Kg} / \mathrm{m}^{2}$. Group 2 included 33 students with BMI $>! 30 \mathrm{Kg} / \mathrm{m}^{2}$.

Results: There was significant difference between the two groups in weight, waist circumference and waist hip ratio, but not for height. As regards CRP serum level, the obese group showed significant increase in serum level. In the same time there was a significant positive correlation between the CRP serum level and BMI, WC and WHR in both groups. On the other hand, protein intake was significantly higher in obese group than normal weight group, as a part of increased caloric intake. When comparing serum uric acid level in the two groups there was a statistically significant difference, and on searching for a relation between the serum uric acid and BMI, WC, CRP and protein intake serum level, a positive correlation was found.
\end{abstract}

Conclusion: Serum UA level is a crucial biomarker, it could induce inflammation and hence increases adiposity or its increase results from increased obesity. Moreover, increased serum uric acid is correlated to increased protein intake in obese individuals with increased total caloric intake specially protein content.

Key Words: Uric acid - Protein intake - CRP - Inflammation - Obese-Medical students.

Correspondence to: Dr. Marian M.S. Roushdy, E-Mail: marianmaher@med.asu.edu.eg

\section{Introduction}

THE high prevalence of overweight and obesity represents a great challenge for prevention of chronic diseases [1]. The first step in community health planning is screening and categorizing overweight and obesity via easy and precise methods [2]. Obesity, defined as excess of body fat, can be detected accurately using Dual-energy X-ray Absorptiometry (DEXA) and Magnetic Resonance Imaging (MRI) techniques [3]. However, these methods, in addition to being expensive and time consuming, require special skills and they cannot be easily performed in large groups of population. Body Mass Index (BMI) is considered an accepted method for screening general obesity and can represent overall obesity without providing any information about body fat distribution in particular [4]. The use of waist circumference measurements is less time-consuming, convenient and simple method. It has also been suggested that WHR can be used for assessing central obesity, visceral fat and the risk factors for chronic diseases [5]. Also, Waist/Hip Ratio (WHR) is suggested as an anthropometric indicator to assess central adiposity.

The exact cause of obesity is not exactly certain; however, it seems like a combined relationship among biologic, psychosocial, and behavioral factors, which include genetic makeup, socioeconomic status, and cultural influences [6].

As discussed previously adipose tissue is characterized by increased production of proinflammatory cytokines such as tumor necrosis factor-a (TNF), interleukin-6 (IL-6), and interleukin-1 0 (IL-1 $\beta$ ), which may generate a frame of chronic low-grade inflammation [7]. Besides those cytokines, obese individuals present high concen- 
trations of C-Reactive Protein (CRP), an acute phase inflammatory marker mainly produced in the liver in response to IL-6 [8]. On the other hand, Uric Acid (UA), the final product of purine degradation, has been associated with obesity. Besides this UA was found to stimulate the release of chemokine monocyte chemoattractant protein-1 and interleukin-1 $\beta$ (IL-1 $\beta$ ), interleukin-6 (IL-6), and tumor necrosis factor- $\alpha$ (TNF- $\alpha$ ) synthesis [9] Uric Acid (UA), the final product of purine degradation, has been associated with obesity.

\section{Subjects and Methods}

Type of study: Case control study.

Study setting: The study was conducted at Ain Shams University (ASU) Hospitals.

Study period: From Jan. 2020 - March 2020.

Sampling method: This study was performed on simple random sample. study.

Sample size: 63 students were included in this

Age: Age group ranges from 19 to 24 years.

Gender: No sex predilection.

Inclusion criteria: Medical students with BMI between $18.5-24.9 \mathrm{Kg} / \mathrm{m}^{2}$ and students with BMI $\geq 30 \mathrm{Kg} / \mathrm{m}$.

Exclusion criteria: Students on corticosteroids, students with autoimmune or other inflammatory diseases, students with incomplete data.

Consent: A written informed consent was obtained from each student after explaining the aim of the study \& all the procedures that were done. Privacy \& confidentiality were concerned. Approval was obtained from the ethical committee. The study was conducted according to the stipulations of the ASU ethical and scientific committee.

Study method: Convenience sample.

Study tools: Using the data supplied by the participants project.
Physical examination: Anthropometric data: Weight, height, body mass index, waist, waist hip ratio.

Laboratory investigations: Serum Uric acid level (method of measurement: Colorimetric) and Serum hs-CRP (method of measurement: Turbidimetry).

Dietary assessment: Dietary protein intake (method: Food composition analysis software).

\section{Statistical analysis:}

The collected data was coded, tabulated, and statistically analyzed using IBM SPSS statistics (Statistical Package for Social Sciences) software version 22.0, IBM Corp., Chicago, USA, 2013 and Microsoft Office Excel 2007.

Descriptive statistics was done for quantitative data as minimum \& maximum of the range as well as mean $\pm \mathrm{SD}$ (standard deviation) for quantitative normally distributed data, median and 1 st $\& 3$ rd inter-quartile range for quantitative non-normally distributed data, while it was done for qualitative data as number and percentage. Inferential analyses was done for quantitative variables using ShapiroWilk test for normality testing, independent $t$-test in cases of two independent groups with normally distributed data and Mann whiteny $U$ in cases of two independent groups with non-normally distributed data. In qualitative data, inferential analyses for independent variables was done using Chi square test for differences between proportions. While correlations was done using spearman rho test for numerical non normally distributed and qualitative data. Linear regression model was used to find out independent factors affecting serum hepcidin. The level of significance was taken at $p$-value $<0.050$ is significant, otherwise is nonsignificant.

\section{Results}

Statistical results:

Descriptive statistics of the studied subjects:

Table (1): Demographic and anthropometric characteristics of studied groups.

\begin{tabular}{lccccccc}
\hline $\begin{array}{l}\text { Study } \\
\text { groups }\end{array}$ & No & $\begin{array}{c}\text { Age (years) } \\
\text { Mean } \pm \text { SD }\end{array}$ & $\begin{array}{c}\text { Age } \\
\text { range }\end{array}$ & Significance & Male & Female & Significance \\
\hline Control & 30 & $21.5 \pm 1.9$ & $18-24$ & $t=-1.784$ & $7(23.3 \%)$ & $23(76.6 \%)$ & U $=-0.199$ \\
Case & 30 & $22.3 \pm 1.7$ & $18-25$ & $p=0.079$ & $7(21.2 \%)$ & $26(78.7 \%)$ & $p=0.843$ \\
\hline
\end{tabular}

$t$ : Independent - Samples $t$-test.

$\mathrm{U}:$ Mann Whitney test (Chi-Square value)

$*: p<0.05$ : Is significant but $p>0.05$ : Is not significant. 
The ages of the participants ranged from 18 to 25 years, 14 of them were males and 49 were females. There was no statistical significance for age and sex between different study group.

Anthropometric measures in different study groups: As regards the relation of waist circumference measurement, waist/hip ratio and our study groups there was a significant difference between the lean group and the obese group in females and males there was a significant difference between the lean group and the obese group with a $p$-value of $(0.000 *, 0.001 *)$ and $(0.034 *, 0.047 *)$. While height measurements were non sigificant with $p$ value of (0.446) between study groups.

Table (2): Comparing the significance of anthropometric measures in different study groups.

\begin{tabular}{|c|c|c|c|c|c|c|c|c|}
\hline \multirow{2}{*}{ Groups } & \multicolumn{2}{|c|}{ Height } & & \multicolumn{2}{|c|}{ Waist circumferance } & & \multicolumn{2}{|c|}{ Waist/hip ratio } \\
\hline & Mean \pm SD & Range & & Mean \pm SD & Range & & Mean \pm SD & Range \\
\hline \multirow[t]{2}{*}{ Lean } & $164.67 \pm 8.3$ & $151-181$ & F & $76.15 \pm 4.8$ & $70-85$ & $\mathrm{~F}$ & $0.77 \pm 0.05$ & $0.65-0.86$ \\
\hline & & & M & $77.21 \pm 7.2$ & $70-90$ & M & $0.84 \pm 0.05$ & $0.78-0.94$ \\
\hline \multirow[t]{2}{*}{ Obese } & $163.16 \pm 7.3$ & $150-183$ & $\mathrm{~F}$ & $98.55 \pm 8.5$ & $89-115$ & $\mathrm{~F}$ & $0.79 \pm 0.16$ & $0.8-1.04$ \\
\hline & & & M & $105.14 \pm 9.9$ & $89-119$ & M & $0.91 \pm 0.05$ & $0.86-1.01$ \\
\hline \multirow[t]{2}{*}{$t$ or $\mathrm{U}$} & \multirow{2}{*}{\multicolumn{2}{|c|}{$t=0.776$}} & $\mathrm{~F}$ & \multirow{2}{*}{\multicolumn{2}{|c|}{$\begin{array}{l}\mathrm{U}=0.000 \\
\mathrm{U}=1.000\end{array}$}} & $\mathrm{~F}$ & \multirow{2}{*}{\multicolumn{2}{|c|}{$\begin{array}{l}t=-2.181 \\
t=-7.896\end{array}$}} \\
\hline & & & M & & & M & & \\
\hline \multirow[t]{2}{*}{$p$-value } & \multirow{2}{*}{\multicolumn{2}{|c|}{0.446}} & $\mathrm{~F}$ & \multirow{2}{*}{\multicolumn{2}{|c|}{$\begin{array}{l}p=0.000^{*} \\
p=0.001 *\end{array}$}} & $\mathrm{~F}$ & \multirow{2}{*}{\multicolumn{2}{|c|}{$\begin{array}{l}p=0.034^{*} \\
p=0.047^{*}\end{array}$}} \\
\hline & & & M & & & M & & \\
\hline
\end{tabular}

$t$ : Independent - Samples $t$-test

$\mathrm{U}$ : Mann Whitney test (Chi-Square value).

$p<0.05$ : Is significant but $p>0.05$ : Is not significant.

CRP serum levels:

A- CRP serum levels in different study groups:

Table (3): Comparing the significance of CRP serum level in different study groups.

\begin{tabular}{lccl}
\hline \multirow{2}{*}{ Groups } & \multicolumn{3}{c}{ CRP } \\
\cline { 2 - 4 } & Mean $\pm \mathrm{SD}$ & Median & Range \\
\hline Lean & $2.6 \pm 1.3$ & 2.25 & $0.5-5.5$ \\
Obese & $9.5 \pm 6.8$ & 10 & $7.7-10$ \\
$\mathrm{U}$ & & $\mathrm{U}=-6.926$ & \\
$p$-value & & $0.000^{*}$ & \\
\hline
\end{tabular}

U: Mann Whitney test (Chi-Square value).

$*: p<0.05$ : Is significant but $p>0.05$ : Is not significant.

CRP serum level was found to be significantly higher in obese individuals than the lean individuals with a $p$-value of $\left(0.000^{*}\right)$.

$B$ - Correlation between CRP serum levels and different anthropometric measures:

Table (4): Correlation between CRP serum levels and BMI, waist circumferance and waist/hip ratio.

\begin{tabular}{cccc}
\hline & BMI & Waist circumferance & Waist/hip ratio \\
\hline CRP & $\rho=0.787$ & $\rho=0.745$ & $\rho=0.267$ \\
& $p=0.000^{*}$ & $p=0.000^{*}$ & $p=0.035^{*}$ \\
\hline
\end{tabular}

$\rho:$ Spearman correlation (non-parametric).

$*: p<0.05$ : Is significant but $p>0.05$ : Is not significant.
Regarding the correlation between CRP serum levels and different anthropometric measures (BMI, waist circumference and waist/hip ratio) there was a statistically significance difference, with a $p$ value of $\left(0.000^{*}, 0.000^{*}, 0.035^{*}\right)$ successively showing positive correlation.

Uric acid serum levels:

A- Uric acid serum levels in different study groups:

Table (5): Comparing the significance of uric acid serum level in different study groups.

\begin{tabular}{llcc}
\hline \multirow{2}{*}{ Groups } & \multicolumn{3}{c}{ Uric Acid } \\
\cline { 2 - 4 } & Mean $\pm \mathrm{SD}$ & Median & Range \\
\hline Lean & $8.9 \pm 1.7$ & 8.7 & $5.3-12.1$ \\
Obese & $10.3 \pm 1.90$ & 10.2 & $7.2-17.9$ \\
$t$ & & $t=-3.094$ & \\
$p$-value & & $0.003^{*}$ & \\
\hline
\end{tabular}

$\mathrm{U}$ : Mann Whitney test (Chi-Square value).

$t$ : Independent-Samples $t$-test.

$: p<0.05$ : Is significant but $p>0.05$ : Is not significant.

Uric acid serum level was found to be significantly higher in obese individuals than the lean individuals with a $p$-value of $(0.003 *)$.

\section{$B$ - Correlation between uric acid serum levels and different anthropometric measues:}

Regarding the correlation between uric acid serum levels and different anthropometric measures 
BMI, waist circumferance and waist/hip ratio there was a statistically significance difference with a $p$-value of $\left(0.020^{*}, 0.024^{*}\right)$ successively showing positive correlation. As for WHR there was no statistically significance difference, between WHR serum uric acid with a $p$-value of (0.251).

Table (6): Correlation between uric acid serum levels and $\mathrm{BMI}$, waist circumferance and waist/hip ratio.

\begin{tabular}{cccc}
\hline & BMI & Waist circumferance & Waist/hip ratio \\
\hline Uric Acid & $\rho=0.293$ & $\rho=0.284$ & $\rho=0.147$ \\
$p=0.020^{*}$ & $p=0.024^{*}$ & $p=0.251$ \\
\hline
\end{tabular}

$\rho$ : Spearman correlation (non-parametric).

$r$ : Pearson correlation (parametric).

$*: p<0.05$ : Is significant but $p>0.05$ : Is not significant.

\section{C- Correlation between uric acid Serum levels and} CRP:

Table (7): Correlation between uric acid serum levels and CRP.

\begin{tabular}{cc}
\hline & CRP \\
\hline Uric Acid & $r=0.293$ \\
& $p=0.020^{*}$ \\
\hline
\end{tabular}

$r$ : Spearman correlation (non-parametric).

$*: p<0.05$ : Is significant but $p>0.05$ : Is not significant.

Regarding the correlation between uric acid serum levels and CRP there was a statistically significance difference with a $p$-value of $\left(0.020^{*}\right)$ showing positive correlation.

\section{Protein intake:}

\section{A- Protein intake in different study groups:}

Table (8): Comparing the significance of protein intake serum level in different study groups.

\begin{tabular}{lccc}
\hline \multirow{2}{*}{ Groups } & \multicolumn{3}{c}{ Protein intake } \\
\cline { 2 - 4 } & Mean $\pm \mathrm{SD}$ & Median & Range \\
\hline Lean & $1.12 \pm 0.19$ & 1.1 & $0.47-1.39$ \\
Obese & $1.31 \pm 0.26$ & 1.2 & $1.01-2.05$ \\
U & & -2.438 & \\
$p$-value & & $0.015^{*}$ & \\
\hline
\end{tabular}

U: Mann Whitney test (Chi-Square value).

$*: p<0.05$ : Is significant but $p>0.05$ : Is not significant.

Protein intake serum level was found to be significantly higher in obese individuals than the lean individuals with a $p$-value of $\left(0.015^{*}\right)$.

\section{$B$ - Correlation between uric acid serum levels and protein intake:}

Regarding the correlation between uric acid serum levels and protein intake there was a statistically significance difference with a $p$-value of $\left(0.017^{*}\right)$ showing positive correlation.
Table (9): Correlation between uric acid serum levels and protein intake.

\begin{tabular}{cc}
\hline & Protein intake $/ \mathrm{kg}$ \\
\hline Uric Acid & $\begin{array}{l}r=0.300 \\
p=0.017 *\end{array}$ \\
\hline
\end{tabular}

$\rho:$ Spearman correlation (non-parametric)

*: $p<0.05$ : Is significant but $p>0.05$ : Is not significant.

\section{Discussion}

Obesity has been considered as one of the most neglected public health problems, affecting both developed and developing countries [10]. The prevalence of obesity has increased markedly in the last few decades [11] and a further increase is expected in the future due to high consumption of high-calorie diets and a sedentary lifestyle.

Obesity is usually defined as body mass index $\left(\mathrm{BMI}=\mathrm{kg} / \mathrm{m}^{2}\right)$. Specifically, overweight is defined as a BMI between $25.0-29.9 \mathrm{~kg} / \mathrm{m}^{2}$ and obesity is defined as a BMI of $\geq 30.0 \mathrm{~kg} / \mathrm{m}^{2}$ [10]

The exact cause of obesity is unknown; however, there appears to be a complex relationship among biologic, psychosocial, and behavioral factors, which include genetic makeup, socioeconomic status, and cultural influences [6]

It is evidently reported that pro-inflammatory markers were significantly higher in obese patients compared to healthy individuals. Furthermore, obese patients with high IL-6 levels also had increased CRP levels, which is a critical risk factor for cardiovascular diseases and type 2 diabetes. On the other hand, UA stimulates the release of chemokine monocyte chemoattractant protein-1 and interleukin-1 $\beta$ (IL-1 $\beta$ ), interleukin-6 (IL-6), and tumor necrosis factor- $\alpha$ (TNF- $\alpha$ ) synthesis [9] Uric Acid (UA), the final product of purine degradation, has been associated with obesity.

In an attempt to clarify the relationship of UA with the systemic inflammatory response, we investigated the relationship between serum UA levels and inflammatory biomarkers as CRP in relation to obesity and relation of protein intake to uric acid production or in other words UA serum level.

The present study included 63 subjects: 30 students with BMI between $18.5-24.9 \mathrm{~kg} / \mathrm{m}^{2}$ and 33 students with BMI $\geq 30 \mathrm{~kg} / \mathrm{m}^{2}$. This study is a part of the Nutritional Assessment of Medical Students of Ain Shams University (NAMS/ASU), the project was designed to evaluate the nutritional status of the undergraduate medical students. All 
participants were subjected to taking of full medical history, 24hrs food recall, general clinical examination, and assessment of the anthropometric measurement. A serum sample was obtained from all subject to estimate their serum levels of hs-CRP and uric acid. Finally, the dietary protein intake was assessed through the food composition analysis software according to Egyptian Food Composition tables was prepared by National Nutrition Institute (National Nutrition Institute, 2006).

Regarding anthropometric measures, heightand weight-based measurements are the most practical tools for assessing nutritional status because of their simplicity and low cost. Of these tools, Body Mass Index (BMI) is recommended as a globally accepted index for screening general obesity and can represent overall obesity without providing any information about body fat distribution and in particular, abdominal obesity [4]. Accordingly, in our study we divided the students into two groups depending on the BMI control group with BMI between $18.5-24.9 \mathrm{~kg} / \mathrm{m}^{2}$ and obese group with BMI $>30 \mathrm{~kg} / \mathrm{m}^{2}$. And as expected the weight measurements were significantly higher in the case group than the control individuals. As regards the relation of waist circumference measurement, waist/hip ratio in our study groups there was a significant difference between the lean group and the obese group.

CRP was measured in serum of all 63 subjects. Serum levels were higher in obese group when compared to control individuals. As part of being a marker of inflammation in confirming the role of adipose tissue in initiating and sustaining low grade of inflammation, significant difference in its levels between patients and control group is expected. This was in agreement with many literatures as Aneta et al., [12]

It is not surprising to find significant relationship between CRP and waist circumferenc, CRP and waist/hip ratio, which is an indicator of visceral obesity since, according to current knowledge, the principal place of production of inflammatory cytokines and proteins is visceral tissue. This finding was also in agreement with previous studies [12].

On the other hand, protein intake was significantly higher in obese group than normal weight group, as a part of increased caloric intake. When comparing serum uric acid level in the two groups there was a statistically significant difference as other studies [13], and on searching for a relation between the serum uric acid and BMI, WC, CRP and protein intake serum level, a positive correlation was found. This indicates that whenever BMI [13] WC [13], CRP [14] and protein intake [15] increase the serum uric acid level increases. The above data shows the mutual relation between uric acid and obesity as well as inflammation. In other words, increased UA level could be caused by increased purine catabolism due to increased protein intake as a part of increased caloric intake in obese, or due to increased adipose tissue hypoxia creating a state of low-grade inflammation and so XOR activity and thus uric acid production. Another explanation could be due to the state of low-grade inflammation caused by UA production that leads to NADP oxidase activity in adipocytes and thus increasing the CRP level and inducing adipogenesis.

\section{Conclusion:}

Results suggest that CRP as an inflammatory biomarker that plays a role obesity. As low grade inflammatory process associated with obesity is reflected on the CRP serum level in otherwise healthy individuals. Additionally, Uric Acid serum level is a crucial biomarker, it could be a cause that induce inflammation and hence increases adiposity or its increase results from increased obesity. Moreover, increased serum uric acid is correlated to increased protein intake in obese individuals with increased total caloric intake specially protein content.

\section{References}

1- TUTUNCHI H., ASGHARI JAFARABADI M., HOOJEGHANI S., TABRIZI S., FARRIN N., PAYAHOO L., et al.: "General and abdominal obesity is related to socioeconomic status and food choices: A cross-sectional study". Nutr. Food Sci., 50 (1): 61-73: 2019.

2- HOSEINIKHORRAMI S., DASTGIRI S., BAKHTARI F. and TUTUNCHI H.: "Epidemiology of food insecurity in the North West of Iran". Res. J. Biol. Sci., 2 (4): $472-$ $5,2007$.

3- NEELAND I.J., GRUNDY S.M., LI X., ADAMS-HUET B. and VEGA G.L.: "Comparison of visceral fat mass measurement by dual-X-ray absorptiometry and magnetic resonance imaging in a multiethnic cohort: The Dallas Heart Study". Nutr. Diabetes, 6 (7): e221, 2016.

4- TUTUNCHI H., OSTADRAHIMI A., HOSSEINZADEHATTAR M.J., MIRYAN M., MOBASSERI M. and EBRAHIMI-MAMEGHANI M.: "A systematic review of the association of neuregulin 4 , a brown fat-enriched secreted factor, with obesity and related metabolic disturbances". Obes. Rev., 21 (2): e12952, 2020.

5- AHMAD N., ADAM S.I., NAWI A.M., HASSAN M.R. and GHAZI H.F.: "Abdominal obesity indicators: Waist circumference or waist-to-hip ratio in Malaysian adults population". Int. J. Prev. Med., 7: 82, 2016.

6- SKELTON J.A., IRBY M.B., GRZYWACZ J.G. and MILLER G.: "Etiologies of obesity in children: Nature 
and nurture". Pediatr. Clin. North Am., 58 (6): 1333-54, 2011.

7- GALIC S., OAKHILL J.S. and STEINBERG G.R.: "Adipose tissue as an endocrine organ". Mol. Cell. Endocrinol., 316: 129-39, 2010

8- LAU D.C., DHILLON B., YAN H., SZMITKO P.E. and VERMA S.: "Adipokines: Molecular links between obesity and atheroslcerosis". Am. J. Physiol. Heart Circ. Physiol., 288: H2031-2041, 2005.

9- JOHNSON R.J., RODRIGUEZ-ITURBE B., KANG D.H., FEIG D.I. and HERRERA-ACOSTA J.A.: "Unifying pathway for essential hypertension". Am. J. Hypertens, 18: 431-40, 2005.

10- DAHIYA P., KAMAL R. and GUPT R.: "Obesity, periodontal and general health: Relationship and management:" Indian J. Endocr. Metab., 16: 89-93, 2012.

11- JAGANNATHACHARY S. and KAMARAJ D.: "Obesity and periodontal disease:" J. Indian Soc. Periodontol., 14: 96-100, 2010

12- ANETA FRONCZYK, PIOTR MOLEDA, KRZYSZTOF
SAFRANOW and WIESLAW PIECHOTA: "Increased Concentration of C-Reactive Protein in Obese Patients with Type 2 Diabetes Is Associated with Obesity and Presence of Diabetes but Not with Macrovascular and Microvascular Complications or Glycemic Control". Inflammation, 37 (2): 349-57, 2014.

13- BINOD K. YADAV1, GOKUL B. CHHETRI, BIBEK POUDEL, MANOJ SIGDEL, PRAJWAL GYAWALI, PRASHANT REGMI and ROJEET SHRESTHA: "serum uric acid in obese and obese indivuadals". Journal of Nepal Association for Medical Laboratory Sciences, 2730, 2009.

14- PUDDU P., PUDDU G.M., CRAVERO E., VIZIOLI L. and MUSCARI A.: "Relationships among hyperuricemia, endothelial dysfunctionand cardiovascular disease: Molecular mechanisms andclinical implications". J. Cardiol., 59: 235-42, 2012

15- PABLO H., JORDI S., MIGUEL R., et al.: "High dietary protein intake is associated with an increased body weight and total death risk". Clinical Nutrition, 35 (2): 469-506, 2016.

\section{مستوى حمض اليوريك في الدم والإلتهابات لدى طلبة جامعة عين شمس الدم}

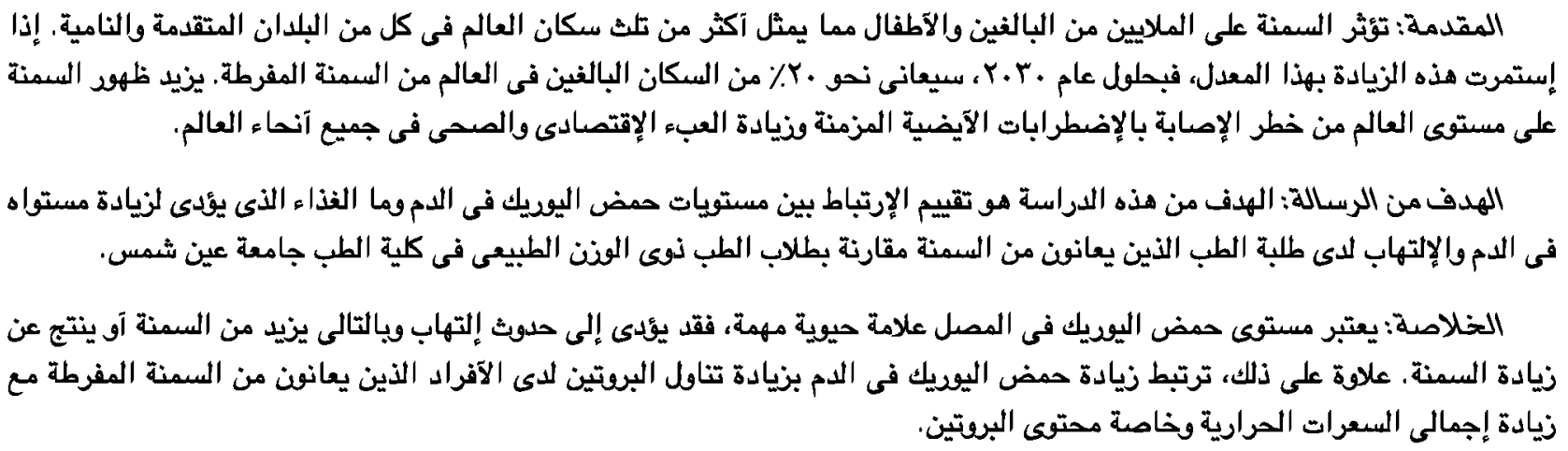

